\title{
E. F. Schumacher: Changing the Paradigm of Bigger Is Better
}

\author{
Roli Varma \\ University of New Mexico
}

In the mid-1970s, the phrase "small is beautiful" became a counterculture slogan against the industrial threat to the environment and the scarcity of resources. Arguing against excessive materialism and meaningless growth, the late Dr. Ernest Friedrich Schumacher-the author of Small Is Beautiful: Economics as if People Mattered, promoted the use of small-scale technology to benefit both humankind and the environment. As an economist trained in a marketoriented discipline, his thinking evolved from believing that large-scale technology could be salvation for industrial civilization to believing that large-scale technology is the root of degrading human beings and the environment.

Keywords: appropriate technology, technological development, social aspect of technology, small is beautiful

$\mathrm{T}_{\mathrm{he}}$ he case against the use of large-scale technology was made by Schumacher between the early 1950s and the late 1970s. It is still legitimate today. Walt Rostow's (1960) high-mass consumption age has led to many serious problems in industrial countries. Al Gore (1992) expressed that global warming, stratospheric ozone depletion, loss of living species, and deforestation have been disrupting the earth's ecological system. Burning gasoline fills cities with fumes and creates air pollution. Chemical and nuclear energy and the high rate of depletion of fossil fuels for industries leave future generations in disarray. For mechanization of agriculture to work, 40 calories have to be spent to produce a calorie worth of food. Since 1950, the number of insects resistant to insecticides has been growing. The individual finds himself or herself fur- ther and further removed from many of the major decisions taken by the society in which he or she lives. Less developed countries face additional problems of drain on foreign reserves, technological dependence, high unemployment rate, and severe poverty.

With a diagnosis of the crisis threatening Western and less developed countries, Schumacher (1973) challenged the modern belief that "bigger is better" and replaced it with "small is beautiful" (p. 150). He forcefully argued that bigness is impersonal, is insensitive, and has lust to power; smallness, on the other hand, is free, efficient, creative, enjoyable, and enduring. The most important area in which he sought to implement smallness was technology, mostly because the modern world has been shaped by it. Schumacher suggested that the less developed countries should not imitate Western technological development based on the trickle-down approach; instead, the less developed countries should embrace an alternative path of development that is less expensive and thus within reach of ordinary people but more productive than indigenous technology.

What makes Schumacher's work remarkable is the philosophical themes woven around the low-cost, small-scale technology as an alternative to high-cost, large-scale technology. This article is divided into three sections. The first section outlines the essential ideas of Schumacher on orthodox economics, industrial production, materialism, social aspects of technology, Buddhist economics, Western technology in the less developed countries, and intermediate technology. This is followed by a critical examination of Schumacher's main thesis, whether small is indeed beautiful. The final section concludes with a brief life history of Schumacher. 


\section{Schumacher's Philosophical Outlook}

\section{The Myth of Objectivity in Orthodox Economics}

Since the publication of Adam Smith's Wealth of Nations in 1776, mainstream economists have pushed for economics to be a value-free objective science similar to the physical sciences. According to them, economics makes positive statements about facts, which are verifiable in principle. Based on definitions and assumptions, hypotheses are formulated as statements about the world in which we live. These statements are then subject to rigorous analysis on the basis of logic, mathematical principles, and statistical techniques. If proven, they predict how people, things, and systems behave under given conditions. These scientific procedures are seen as neutral and thus eliminate the normative aspects of economics. Accordingly, in 1969, the Nobel Prize for "economic science" was established. As Professor Erik Lundberg observed, "Economic science has developed increasingly in the direction of a mathematical specification and statistical quantification of economic contexts" and has left behind "the vague, more literary type of economics" (as cited in Roszak, 1973, p. 1).

Schumacher argued against the myth of objectivity in orthodox economics. According to him, unlike the physical sciences, economics is concerned with human choices and actions, which by their very nature introduce value elements. Numbers that are relied on by economists to be objective are often misleading in reference to human beings. Numbers by themselves have no meaning unless significance is established. For example, "the substance of man cannot be measured by Gross National Product. Perhaps it cannot be measured at all, except for certain symptoms of loss.... Statistics never prove anything" (Schumacher, 1973, p. 19). His "theory has always been that figures don't mean anything if you can't make them sing" (Schumacher, 1979, p. 125). Once meaning is attached to numbers, they are no longer neutral.

Another example of facts being tainted with values in orthodox economics is in the area of money. Schumacher (1967/1982) found this field relies heavily on the single coefficient of money because it is concerned mostly with the ability to earn an adequate short-term profit. As a result, economic activities that are likely to lower short-term monetary profits tend to be placed outside of orthodox economics. For example, the practice of environmental conservation has

no acknowledged place in a society under the dictatorship of economics. When it is occasionally introduced into the discussion, it tends to be treated not merely as a strange but as an undesirable alien, probably dishonest and almost certainly immoral. (p. 17)

\section{The Problem of Industrial Production}

The economy of Western countries is industrialized, based on a complex infrastructure and high productivity. Industrial enterprises manufacture a large volume of products at a low cost. Furthermore, they provide decent employment so people can buy products; real personal income has risen to a point that transcends basic necessities such as food, clothing, and shelter. The output per worker is high because the production depends on the potentialities created by modern science and technology. Agriculture is mechanized and approximately $20 \%$ of the population depends on it. To maintain production, necessary infrastructures such as roads, transportation, and electricity have been developed. Such industrial economies have been hailed as panacea to all sorts of economic and social problems. It is believed that Western societies' wellbeing is contingent on the continuous industrial expansion. Unless there is an increase in industrial production, they will suffer stagnant or lower living standards.

Western countries have based their industrial production on various sources of energy such as oil, natural gas, nuclear, and coal. Schumacher (1973), therefore, examined facts and figures about the growth of energy production, consumption, demand, and supply. He found industrial production to be predominantly based on nonrenewable sources of energy, which are finite and thus cannot be replaced after they were consumed. In other words, the world will eventually run out of energy resources with the current consumption rate. In the era of industrial expansion, Schumacher argued against industrial production that assumed limitless fossil fuels. He stated that

one of the most fateful errors of our age is the belief that the problem of production has been solved. This illusion ... is mainly due to our 
inability to recognize that the modern industrial system, with all its intellectual sophistication, consumes the very basis on which it has been erected.... It lives on irreplaceable capital which it ... treats as income. (p. 19)

He warned that industrial countries contain the seeds of their own destruction.

According to Schumacher, profligate use of natural resources has also brought on the crisis of the environment. For instance, replacing fossil fuels with the use of nuclear energy means solving "the fuel problem by creating an environmental and ecological problem of such a monstrous magnitude" (Schumacher, 1973, p. 18). Similarly, the "qualitative jump" in the production of synthetic compounds unknown to nature has pushed nature's "tolerance margins." Such dangerous ecological impact threatens to destroy the earth. He opposed those practices of the modern world that seek to mobilize more resources to fight pollution or discover new sources of fossil fuels-because they do not change the methods of industrial production.

\section{Danger in Materialism}

Materialism holds that the world is by its very nature material; the world consists of particles of matter; each of them has its own existence. These particles interact with each other and in their totality form the world. Matter is objective reality existing outside and independent of the mind; anything mental or spiritual is a product of material processes. Materialism is based on the scientific investigations of natural phenomena and thus seeks explanations in terms of factors that can be verified. It views each human being as a social atom with certain inherent properties and attributes. In the industrial system of production, materialism has been reduced to the ideology of market. The market is seen both as the natural condition of mankind and irresistible; it gives the people what they want. The production and consumption of material goods and the acquisition of money are the main goals of the market. It is believed that the generation of wealth will result in satisfaction with nonmaterial goods such as justice, harmony, happiness, beauty, and health.

Against materialism, Schumacher believed in idealism, which views spiritual as prior to the material. For him, there was a higher, more real, and nonmaterial world beyond the material world. He believed that the problem of industrial production resulting in the envi- ronmental crisis stemmed from misplaced values. Unlike religious teachings, materialism shows no selfcontrol or respect with the natural world. Schumacher (1977) made a distinction between "convergent" and "divergent" problems (p. 121). Convergent problems relate to the nonliving aspect of the world; in contrast, divergent problems relate to the human issues. With convergent problems, scientific investigations tend to find solutions; the answers tend to converge. However, with divergent problems, scientific investigations lead to opposite solutions; the answers tend to diverge. Schumacher believed that materialism treats all problems as convergent and thus dehumanizes individuals. He therefore suggested a return to religious truth. In his words, "the modern experiment to live without religion has failed" (p. 139).

Schumacher thought of the materialist philosophy of overproduction and overconsumption as a root of many problems facing the modern world. For instance, the practice of mechanized agriculture and factory farming adds to the pollution of land and water. Similarly, increasing wealth of people depends on making continuous demands on limited world resources. Schumacher (1973) questioned measuring a man's "standard of living" by assuming that a "man who consumes more is 'better off' than a man who consumes less" (p. 54). He believed that material prosperity could not lead to world peace because "it is attainable only by cultivating such drives of human nature as greed and envy" (p. 30). According to him, "man must never lose his sense of the marvellousness of the world around and inside him" (Schumacher, 1974, p. 31). He therefore promoted "reduction of needs" to promote "peace and permanence" (Schumacher, 1973, p. 31).

\section{The Value of Buddhist Economics}

The economic system of Western countries has been called the private enterprise system. It relies predominately on a market mechanism to determine allocation of resources, production techniques, pricing, and distribution of goods and services. Under a private enterprise system, economic activities are organized via a system of markets through which buyers and sellers interact. Most of the goods and services are provided by the private sector for profit. They decide what is to be produced, how it is to be produced, and for whom it is to be provided. Marxist economists have called the private enterprise system capitalism because of the private ownership of the means of production, 
such as factories, farms, mines, and natural resources. In the international division of nations, Western countries are developed and rich, whereas most African, Asian, and Latin American countries are underdeveloped and poor.

Schumacher (1973) found Buddhist economics to be based on assumptions, which were not in accordance with Western economics. For instance, Buddhist economics "tries to maximize human satisfactions by the optimal pattern of consumption," whereas Western economics "tries to maximize consumption by the optimal pattern of productive effort" (p. 55). In Buddhist economics, a high standard of living depends not on maximizing consumption but on minimizing consumption. Furthermore, Western economics depends on scarce resources to produce and consume material goods; Buddhist economics, on the other hand, views the wasteful use of natural resources as a violent act against the environment, the society, and the living world. By not making consumption the sole end of production activity, Buddhist economics decreases the depletion of scare resources.

In Buddhist economics, work is essential for the happiness and development of each human being. This is in contrast with Western economics, which values work in terms of production. In Schumacher's (1973) words, "one of the basic truths of human existence, namely that work and leisure are complementary parts of the same living process and cannot be separated without destroying the joy of work and the bliss of leisure" (p. 52). Buddhist economics, therefore, views unemployment as an evil because it denies people fulfillment of their potential. "The Buddhist sees the essence of civilization not in a multiplication of wants but in the purification of human character. Character ... is formed primarily by a man's work" (p. 52). In Western economics, the labor is viewed as a cost, which is to be reduced to a minimum. "The basic aim of modern industrialism is not to make work satisfying but to raise productivity: its proudest achievement is labor saving" (Schumacher, 1979, p. 27).

\section{Social Aspect of Technology}

Technology is generally considered socially neutral, possessing an internal objective logic of its own (e.g., Bell, 1980). It is believed that technology develops as a result of an internal dynamic and then molds society to fit its pattern. One of the implications of technology being socially neutral is that technological development is a practical necessity regardless of its consequences. Even when there are some adverse impacts of technology, it remains the necessary price to be paid for the well-being of a society. There is no need to question the nature and structure of technology and the ways in which it has developed historically. Consequently, technology has been hailed as a motor of all progress, the key to solving our social problems, and a source of permanent prosperity. Many believe that scientific and technical progress will cure diseases, improve the quality of life, explore space, and develop faster modes of communication. They imagine a technological future that is filled with neatness and order, endless gadgets to do all the work, superhighways, and virtual reality.

Schumacher also believed that the modern world has been shaped by technology. However, instead of admiring technological determinism, ${ }^{1}$ he showed the destructive impacts of modern technology such as degradation of environment, threat to the existence of human race, depletion of natural resources, and dislocation of labor. He believed that the role of technology in society needs to be debated. Given that technological development is a social process and that the prevailing technology in an industrial society coincides with authoritarian and hierarchical relationships, ${ }^{2}$ it is possible to conceive a technology that is based on nonauthoritarian and nonhierarchical relationships. In other words, there are technological alternatives, and there is no reason to make inappropriate choices in selecting technologies. In Schumacher's (1973) words,

if that which has been shaped by technology, and continues to be so shaped, looks sick, it might be wise to have a look at technology itself. If technology is felt to be becoming more and more inhuman, we might do well to consider whether it is possible to have something better-a technology with a human face. (p. 138)

He therefore believed in a technological fix, using technology to solve economic and social problems.

\section{Inappropriateness of Western Technology}

The core of the development policies of the less developed countries is that by introducing Western technology, they would be revitalized and thus would start growing on their own. A general assumption is that the technological transformation of the less developed countries is synonymous with the whole process 
of socioeconomic development. Less developed countries have taken this path of development mainly because the characteristic feature of the unprecedented epoch of modern economic growth in the West is the use of modern scientific and technological knowledge, which has increased productivity output per unit of all inputs. In contrast, the less developed countries have emerged underdeveloped in relation to the West. Furthermore, the less developed countries have been characterized by the West as "backward," "traditional," and "lacking scientific and technical traditions" and thus are looked down upon. A theory of "modernization," the heart of which is the "transfer of technology" from the West, has extensively been parceled to the less developed countries. Since independence from the colonial powers, the less developed countries have adopted the developmental model of the West.

Concerned about the increasing discrepancy between the rich and poor nations, Schumacher (1973) sought to understand the problems of the less developed countries. He questioned Western technology as a possible solution to the less developed countries' development problems. According to him, in the process of modernization the less developed countries have acquired different production functions in the advanced and traditional sectors. Over all, gains from the growth of the modern sector have been increasing rather than reducing problems of development by deepening dualism between the limited industrial sector and the vast rural hinterland. In his words,

the dual economy, unless consciously counteracted, produces . . . a "process of mutual poisoning," whereby successful industrial development in the cities destroys the economic structure of the hinterland, and the hinterland takes its revenge by mass migration into the cities, poisoning them and making them utterly unmanageable. (p. 158)

According to Schumacher, the West has established large industries with advanced technology in the cities and staffed them with managers. These industries are a product of Western societies, which are rich in capital but short in labor; the less developed countries, on the other hand, are rich in labor but short in capital. These industries make a limited contribution to employment in the less developed countries. Furthermore, Western technology functions differently in the less developed countries because of its different social context. For in- stance, "the system of mass production, based on sophisticated, highly capital-intensive, high energyinput dependent, and human labour-saving technology, presupposes that you are already rich" (Schumacher, 1973, p. 145). As a result, the less developed countries have failed to incorporate Western technology or imitate Western economies.

\section{Intermediate Technology}

Schumacher's greatest contribution has been on the role of intermediate technology for the development of the less developed countries. Schumacher argued that the Western "trickle-down" theory was not leading to the full employment of poor people in the less developed countries, most of whom lived in rural areas. The primary consideration of growth-based development was to maximize output per man in the urban area and not work opportunities for the unemployed and underemployed in the rural area. Furthermore, industrial mode of production was unsustainable because it was based on the depletion of natural resources and the deterioration of the environment. He did not view socialist economics as a possible solution to the less developed countries because the problem was the means of production, not ownership by the capitalist class. He believed that socialist economies were founded on the same unsustainable basis as Western economies.

Schumacher was deeply impressed with the philosophy of Mahatma Gandhi who led the opposition against the British rule of India. Like Gandhi, he felt that Western technology would displace massive labor forces from rural to urban areas without providing full employment. Schumacher also felt that India lacked the infrastructure necessary for such technology. Unlike Gandhi, however, he believed that indigenous technology would be insufficient to improve the economic conditions of rural India. Schumacher (1979, p. 95) set his tasks to create cheap workplaces, locate them in the rural area, employ simple production methods, and use local materials. Instead of "capitalintensive" technology, he sought to employ "laborintensive" technology and lend to "small-scale" establishments. He believed such production methods would be biologically sound, build up soil fertility, and produce beauty and permanence.

This small-scale, inexpensive, labor-intensive, compatible with human needs, and nonviolent to nature technology was named by Schumacher intermediate technology. ${ }^{3} \mathrm{He}$ founded the Intermediate 
Technology Development Group (ITDG) in 1966 to engage in the systematic study on how to help people help themselves. To this day, ITDG makes the less developed countries aware of the alternatives to the high technologies promoted by the West by providing technical assistance.

Schumacher (1973) defined intermediate technology as a "£100-technology" (p. 169). Using equipment cost per workplace as a base, Schumacher called the indigenous technology of the less developed countries a "£1-technology" and the modern technology of the Western countries a "£1000-technology." He saw the less developed countries stagnating with £1-technology. However, he believed the $£ 1,000$-technology from the West killed off the £1-technology and left the poor people of the less developed countries worse off than before. This was mostly because the $£ 1,000$-technology was expensive, complex, and dependent on highenergy input and destroyed indigenous social and economic structures. Schumacher proposed an alternative that was more productive than the traditional technology and still less expensive than Western technology. Schumacher considered the intermediate technology "vastly superior to the primitive technology of bygone ages but at the same time much simpler, cheaper, and freer than the super-technology of the rich" (p. 145). He believed that intermediate technology would promote gradual development of the less developed countries while meeting the needs of ordinary people.

\section{Is Small Beautiful?}

Schumacher's most important claim, that smallscale technology could be the foundation of new society, needs a critical examination. He understood smallscale technology in dichotomous fashion. He saw social, economic, and political problems in a society as being associated with modern large-scale technology; the implementation of alternative small-scale technology was seen as a panacea for all such problems. Some of the characteristics that distinguished alternative from modern technology were small scale versus large scale, inexpensive versus expensive, ecologically sound versus ecologically unsound, small energy input versus large energy input, low pollution rate versus high pollution rate, nonviolent to nature versus violent to nature, decentralist versus centralist, simple versus complex, labor intensive versus capital intensive, compatible with human needs versus incompatible with human needs, reversible use of materials versus nonreversible use of materials, and so forth (Dickson, 1975, pp. 103-104). In the 1970s and 1980s, such a mystifying role of alternative small-scale technology had turned into a theology. People had become devotees of small-scale technology, believing that somehow "the evil" and social ills in their society would be destroyed with its implementation.

Broadly, there are two dominant meanings for alternative small-scale technology, one for industrial countries and the other for the less developed countries. In industrial countries, alternative small-scale technology is understood as one that does not degrade the environment, whereas in the less developed countries, it is understood as one that provides employment to ordinary people.

\section{Alternative Path for Industrial Nations}

The industrial system of the United States alone consumes approximately $30 \%$ of the world's primary resources to support its less than $6 \%$ of the world's population. With this rate of consumption, it is possible that the world could run out of nonrenewable resources in the 21 st century, continuing to increase the level of pollution. The Club of Rome (1972) has argued that if the current growth of population and industrial consumption of natural resources continues, the limits to growth on this planet will occur within the next 100 years because of limited stocks of physical resources. Similarly, the world's consumption of energy for industrial purposes has been doubling approximately once every decade since World War II.

It is undeniable, as Schumacher suggested, that the problems of industrial countries would be less severe if, for instance, energy production were based on using renewable fuels (sun, wind, and vegetation), which would not degrade the environment. However, the question of importance is why alternative energy technologies, despite numerous advantages, do not get developed on a wider scale in industrial countries. Perhaps the answer lies in the lack of a clear vision of how alternative energy technologies could be realized. Schumacher has correctly pointed out that such technologies could develop within the framework of a new value system. But he was silent on major social and political factors that are obstacles to or could promote the development of alternative energy technologies. It is not enough to believe that through alternative energy technologies, one can build society based on demo- 
cratic and egalitarian principles; that is, alternative technologies can shape vested interests. In fact, vested interests can shape alternative technologies to suit their own goals.

A national government, which could develop alternative energy technologies, is not directly involved in the production process in the free enterprise economies of industrial countries. It gives concessions to private enterprises that run, develop, and supply technology on the basis of cost and profit. The government more or less establishes some regulations on energy, but private enterprises determine the nature of it. Alternative energy technologies, therefore, can only develop within the existing framework if it can achieve the goals of profit maximization. Private enterprises, however, have been making profits from technologies that have been the source of many problems. Even with the oil crisis of 1973, "Big Seven" oil companies made higher profits than the pre-1973 era. For instance, Gulf's profits in the first quarter of 1979 jumped $61 \%$, Texaco's 81\%, and Standard Oil of Ohio's 303\% (Barnet, 1980, p. 26). These companies, therefore, have little incentive to switch from oil to solar or wind technology.

Most important, big oil companies have come to control alternative energy technologies such as coal, solar, and wind to avoid competition. Before the oil crisis of 1973, oil companies had acquired control over vast quantities of nonoil energy sources. They held six out of seven outstanding patents of photovoltaic cell areas, which convert sunlight directly into electricity. Shell owned Solar Energy Systems, Exxon controlled Solar Power, and Arco had Solar Tech (Barnet, 1980, p. 103). By controlling other sources of energy supplies, oil companies are able to maximize their profits because nothing else competes with them.

Alternative energy technologies become worth developing by oil companies if they are less expensive than oil technology. Whether the price is right for alternative energy technologies depends on the price of oil. Also, to maximize profit, oil companies explore the development of various energy resources if they are potentially profitable. Initially, the few alternative energy technologies that were developed due to concern shown by ecologists, environmentalists, and the public, as well as increasing costs due to environmental legislation of the 1970 s, remained more expensive than oil technology. This limited the market for solar and wind technologies (Barnet, 1980; Tanzer, 1974).
Schumacher was critical of large-scale energy technologies but shied away from discussing how they were related to the distribution of power and the exercise of social control. The nature of technology development in any society can best be understood by relating technology to the patterns of general economic and social activities that maintain the interest of the dominant social groups in that society.

In the past decade, however, solar and wind cells have emerged as cornerstones of the new energy economy, even though oil and gas remain the main sources of energy consumption. Between 1990 and 1998, world wind-generating capacity expanded $26 \%$ as the cost dropped $\$ 2,600$ per kilowatt in 1981 to $\$ 800$ in 1998 (Brown, Renner, \& Flavin, 2000, pp. 48-49, 5255). Wind power has become one of the world's cheapest sources of electricity. In 1998, sales of solar cells that can convert sunlight into electricity jumped $21 \%$ (Brown et al., 2000, p. 17). Although the annual rate of growth has been increasing for wind and solar, it has been decreasing for nonrenewable sources of energy. For instance, the growth in oil use in 1998 slowed to less than $1 \%$. For the same period, the burning of natural gas increased by only $1.6 \%$, and the nuclear power generation experienced the near zero growth rate (Brown et al., 2000, p. 17). Private companies such as British Petroleum and Royal Dutch Shell have been investing heavily in alternative energy sources. In 1999, Mike Bowlin, chairman and CEO of ARCO, a leading U.S. oil company, acknowledged that the new challenge was to convert the carbon-based world energy economy into one that was based on hydrogen and other forms of energy (as cited in Brown et al., 2000, p. 18).

The emergence of a new energy economy supports Schumacher's thesis that alternative technologies can be developed within the Western system of industrial production. However, alternative energy technologies have become worth developing by the fossil fuel industry mostly because of the high price of oil and the global economic slowdown. Because private enterprises control both nonrenewable and alternative sources of energy, they can have both technological developments as seasonal, depending on their longterm economic interest. In either case, alternative energy technologies are no longer small scale and decentralized; instead, such technologies are large scale and centralized, controlled by big private enterprises. What Schumacher proposed to be small establishments have now become large establishments. 


\section{Alternative Path for Less Developed Countries}

The problems of the less developed countries would be less severe, as Schumacher suggested, if laborintensive technologies were employed that could absorb the unemployed and underemployed members of the labor force. The strategy of heavy industrialization has been rather ineffective in employing the massive labor force of the less developed countries. This is not to deny that there are some countries such as South Korea and Taiwan that have succeeded in increasing industrial employment and are no longer considered less developed. But less developed countries where heavy industrialization has brought a significant change in the employment structure are few compared to those where it has not.

Schumacher employed the notion of intermediate technology and advocated small-scale methods of production for the less developed countries. He believed that the West had mistakenly believed that what is good for them is also good for the less developed countries. So, he suggested that the West should transfer small-scale instead of large-scale technology.

The transfer of technology from the West is carried out via the multinational (or global) corporations. The transfer of technology from the multinational corporations to the less developed countries resembles leasing land under feudalism. A large part of the scientific and technological knowledge that is essential for less developed countries to resemble the industrialization of the West is not freely available to them. There are proprietary rights in technology in the form of patents, trademarks, and brand names; the basic designs, blue prints, and know-how remain in the private possession of multinational corporations. Furthermore, the supply of technology is linked with other services and equipment. Less developed countries have to buy a complete industrial process with preinvestment studies, design of plant, commissioning and construction, start-up, and training by engineering consultants and machinery manufacturers. The multinational corporations maintain a degree of control over the continuing use of the technology even after the plant is built up through partial or complete ownership. Many such contracts also involve restrictive practices such as exclusive grants, challenges to validity of patents, exclusive dealing, and restrictions on research. A consequence is that the less developed countries have been unable to acquire the technology they desire at the right price under the right terms and conditions (see
Barnet \& Muller, 1974; Goulet, 1977). This is why they have demanded a complete transfer of modern science and technology from multinational corporations on better terms (United Nations, 1975). But the less developed countries attempting to unpack the technology have been resisted by multinational corporations, mostly because it threatens their control over technology, markets, and economic gains.

It is unclear why multinational corporations would behave differently in transferring small-scale technologies to the less developed countries than what they have done for large-scale technologies. In other words, transfer of alternative small-scale technology from the West to the less developed countries would continue to lead to technological dependence of the latter. Schumacher was critical of modern technology in the less developed countries but not of the role multinational corporations play in the so-called transfer of technology.

For Schumacher, intermediate technology was the one close to midway between capital-intensive technologies exported by the West and traditional technologies of the less developed countries on the logarithmic scale of cost. Irrespective of his intentions, it can be viewed that he not only promoted technological dependence of the less developed countries on the West but also gave a theoretical rationale for the secondhand and outmoded technologies dumped by multinational corporations in the less developed countries.

It is not true, as Schumacher assumed, that the less developed countries are rejecting the Western model of modernization and development. Schumacher had overemphasized the opening of a cell for alternative technology in 1971 by the Ministry of Industry of the government of India. It is true that it was closely followed by the opening of a number of centers for research into alternative technology in some of the leading Indian technical institutes. But needless to say, the so-called alternative technology program did not get very far in India. Gandhian peasants in India are trying their best to acquire modern industrial agricultural equipment. Far from rejecting Western technology, they are well integrated into a pattern of production based on chemical fertilizer, diesel- or electricpowered machinery, and high-yielding varieties of seeds. Most important, there are many changes that have taken place with the introduction of large-scale technology, such as communication, electricity, electronics, hospitals, media, and transport, with which ordinary people in less developed countries are quite happy. Furthermore, many social practices such as 
untouchability, widow burning, endogamy, witchcraft, quack medicine, and so forth are put to change in the era of large-scale technology. So, it is hard to say that all aspects of large-scale technology are bad and all aspects of small-scale technology are good in the less developed countries.

\section{Concluding Remarks}

Schumacher has shown limitations of large-scale industrialization for both industrial and less developed countries. Both countries have accepted some principles of alternative technological development and devoted some resources to achieve such goals.

Nonetheless, Schumacher's antidote of small is beautiful represented wishful thinking. First, modern technology is many things simultaneously-including a body of empirical knowledge, a corpus of techniques, a method of cognition, and an epistemology. It has grown and developed within the Western society and thus carries a Western worldview. It plays both roles - constructive and destructive - and thus cannot be painted as oppressive per se. Second, the sources of oppression need not lie in modern technology but perhaps in the social structure of a society. If holders of economic and political power use modern technology to suit their vested interests, then the fault lies within the social structure. This is not to deny that the struggle for emancipation from apparently oppressive modern technology coincides with and reinforces the struggle for emancipation from oppressive social structure. Third, alternative paths for development are not well defined. For instance, there are too many qualities of alternative small-scale technology. Different combinations of these qualities would result in an extremely large number, suggesting vast possibilities for alternative technological development and thus making the task unmanageable. Fourth, small-scale technology does not always play a constructive role from the point of view of ordinary people in the less developed countries. To prescribe an antidote that ordinary people should not desire to have sophisticated technical goods or the less developed countries should not hope to resemble the industrialized countries is nothing more than an ethnocentric view.

\section{Schumacher's Life, 1911-1977}

E. F. Schumacher ${ }^{4}$ was born in 1911 in Bonn, Germany. His father, Hermann Schumacher, was a professor of economics and his mother, Edith Zitelmann, was

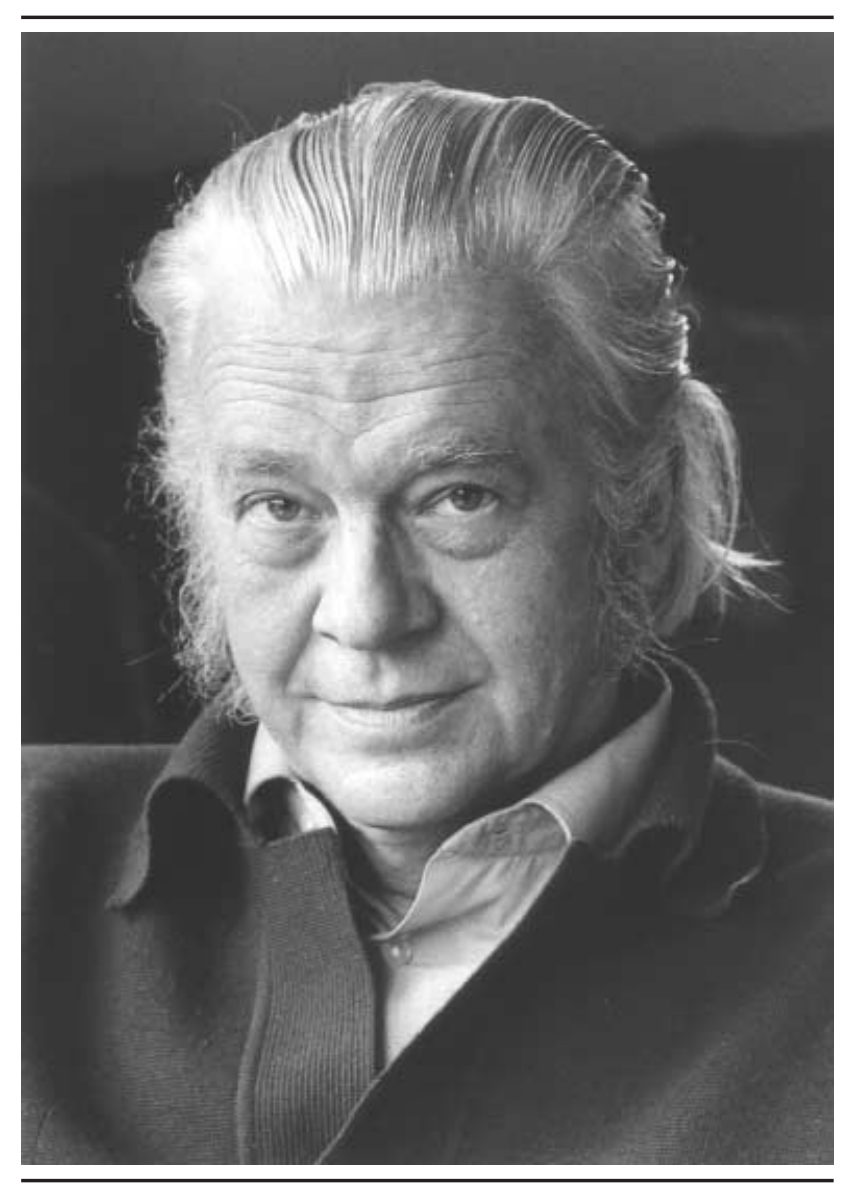

Figure 1: E. F. Schumacher

Source: Reprinted with permission from Sophie Baker.

a mathematician. Following in his father's footsteps, Schumacher studied economics. In 1930, he received a Rhodes scholarship to Oxford University where he earned a degree in politics, philosophy, and economics. After graduating in 1932, he studied and lectured economics at Columbia University. He then believed that "the economist should not be bothered with politics and psychology or such hybrid and pseudoscience as sociology" (Wood, 1984, p. 53). He was trained in pure economic theory, scientific reasoning, and empiricism and had little tolerance of nonscientific thoughts.

In the 1930s, Europe was going through the general economic depression. Nonetheless, Schumacher returned to Germany in 1934 to explore whether one could "lead a moral life within an immoral system without compromise" (Wood, 1984, p. 65). To see if he could make a living with his theoretical knowledge of economics, he set up a consulting firm to advise exporters on trading. As he became critical of Adolf Hitler's regime, Schumacher realized that he could no longer live in Germany. He did not want "to go under- 
ground and play double roles" (Harrison, 1977, p. 36). In 1937, Schumacher immigrated with his first wife Annemarie to England. There, he started a number of companies in the investment and banking fields. Concerned about the future of fossil fuels, he also set up a small company that produced battery-driven vehicles.

As German aggression increased, Schumacher found himself as an enemy alien on British soil. After losing his job, he became a farm laborer in 1939. Shortly after moving to the farm, however, he was forced to enter an internment camp where he met Kurt Naumann, a Marxist. "Poverty and plenty, oppression and justice were put into a new perspective by Marx's penetrating analysis" (Wood, 1984, p. 113). Fortunately, his imprisonment lasted only 3 months. Shortly thereafter, he moved back to the farm. For the next 4 years, he did farming with little use of chemical fertilizers and pesticides. Also, he lived without electricity, gas, and water and thus experienced life without contemporary technology.

Making less than $\$ 4$ a week on the farm, Schumacher wrote papers to make extra money to support his family. Dr. John Maynard Keynes, the famous and leading British economist, read Schumacher's paper about a new international monetary system that would speed up the reconstruction of Germany. Keynes invited Schumacher and eventually he was able to move from farming to the Oxford Institute of Statistics.

In 1946, he was selected to be a member of the British Control Commission on the reconstruction of Germany. Dismayed by the destruction of Germany, Schumacher called to liberalize the restrictions that were cramping several industries. He believed that the reconstruction of Germany as well as the rest of Europe should be based on "large-scale state monopolies" and "mass production" (Wood, 1984, p. 139). Being influenced by Marxist ideology and working with Sir William Beveridge (1945), Joan Robinson (1956), and Richard Titmuss (1959), Schumacher focused on imminent problems of unemployment in Germany. He believed in the "fundamental right of every man to work and earn a living" (Wood, 1984, p. 123). $\mathrm{He}$ also paid close attention to energy concerns because major industries depended on fuel supplies, which was a serious issue in the economic recovery of Germany. He supported reliance on coal when others moved toward oil and nuclear energy. He opposed European dependence on cheap oil from the Middle East. He also was against nuclear energy due to the hazardous nature of technology.
Schumacher's plans for the reconstruction of Germany, however, were rejected. This made him extremely frustrated. "He believed that he possessed resources necessary to find the key to mastering the problems" (Wood, 1984, p. 142). He had little patience for anyone he disagreed with. He began to question his beliefs in economic theory, methods, logic, scientific facts, and empiricism.

In 1950, Schumacher returned to England as an economic advisor to the National Coal Board, a position he held for the next 20 years. Around the same time, he joined the Soil Association to get involved in organic farming. In his countryside home, he grew his own vegetables by using horse manure, compost, and crop rotation. He grounded his own wheat, baked his own bread, and raised his own poultry.

Rethinking his education and training in economics caused him to explore history, philosophy, spiritualism, and eastern religion. Buddhism, which preached nonviolence, moderation, and respect for nature, enlightened him the most. Schumacher declared "good gracious, this is what I've been looking for" (Harrison, 1977, p. 38). In 1955, he went to Burma as an economic adviser to the government and experienced the Buddhist religion in action. After 3 months, he returned from Burma as "a Buddhist" (Wood, 1984, p. 254). Later on in his life, however, he became Roman Catholic. He felt that "what [he] had learned via Buddhism was freely offered to [him] nearer home, in Christianity" (Harrison, 1977, p. 34).

In 1961, J. L. Nehru, the first prime minister of India, invited Schumacher to be a part of the planning commission. Schumacher recommended "intermediate technology" to the Indian planning commission, which was welcomed but not put into place. In 1966, Schumacher founded the ITDG to promote alternative developments of the less developed countries.

On the advice of Robert Swann, an American pacifist and advocate of decentralization, Schumacher published a collection of his articles in book form. His seminal book, Small Is Beautiful: Economics as if People Mattered, published in 1973, was embraced by the environmentalists throughout the world. Twenty years earlier, Schumacher had predicted the approximate date and nature of the energy crisis that the world faced in the 1970s (Wade, 1975). The Western media paid close attention to his tours, and large audiences attended his talks. Several high-level officers including U.S. President Jimmy Carter consulted him on the future of industrial and postindustrial society. The 
book became a countercultural cult of industrial societies, and Schumacher became a guru.

Schumacher died unexpectedly in 1977 in Switzerland when he was stricken with a heart attack. The ecoactivism suffered severely from his death, resulting in a decline in the press coverage and public awareness in many Western countries. Nonetheless, Schumacher's philosophy of social and environmental sustainability is kept alive by a number of organizations, such as the E. F. Schumacher Society (United States), the Schumacher Society (United Kingdom), Schumacher College, the ITDG, Resurgence Magazine, Green Books, the Schumacher Books Service, New Economics Foundation, Orion Society, Second Nature, Center for a New American Dream, Ithaca Hours, Local Currencies and Informal Credit Systems, 21st Century Social Evolution, Thoreau Institute, Second Nature, the Institute for Local Self-Reliance, and the Institute for Sustainable Communities.

\section{Notes}

1. Technological determinism believes that (a) the technical base of a society is the fundamental condition affecting all patterns of social existence and (b) changes in technology are the single most important sources of change in society.

2. Alfred Chandler (1977), coming from a technological deterministic perspective, has shown that the properties of large-scale systems inevitably require centralized, hierarchical managerial control.

3. The idea of intermediate technology is also expressed by using terms such as soft, radical, people, democratic, indigenous, alternative, and appropriate technology.

4. This section relies heavily on the biography of Schumacher by his daughter, Barbara Wood (1984).

\section{References}

Barnet, R. J. (1980). The lean years: Politics in the age of scarcity. New York: Simon \& Schuster.

Barnet, R. J., \& Muller, R. E. (1974). Global reach: The power of the multinational corporations. New York: Simon \& Schuster.

Bell, D. (1980). The winding passage. Cambridge, MA: Abt.

Beveridge, W. H. (1945). Full employment in a free society. New York: Norton.

Brown, L. R., Renner, M., \& Flavin, C. (2000). Vitals signs: The trends that are shaping our future. Washington, DC: World Watch Institute.
Chandler, A. D. (1977). The visible hand: The managerial revolution in American business. Cambridge, MA: Harvard University Press.

Club of Rome. (1972). The limits to growth. New York: Universe Books.

Dickson, D. (1975). The politics of alternative technology. New York: Universe Books.

Gore, A. (1992). Earth in the balance: Ecology and the human spirit. New York: Plume Edition.

Goulet, D. (1977). The uncertain promise: Value conflict in technology transfer. New York: IDOC.

Harrison, P. (1977). The legacy of E. F. Schumacher. Human Behavior, 6, 32-39.

Robinson, J. (1956). The accumulation of capital. London: Macmillan.

Rostow, W. (1960). The stages of economic growth: A non-communist manifesto. Cambridge, UK: Cambridge University Press.

Roszak, T. (1973). Introduction. In E. F. Schumacher, Small is beautiful: Economics as if people mattered (pp. 1-9). New York: Harper \& Row.

Schumacher, E. F. (1967). Clean air and future energy. In G. Kirk (Ed.), Schumacher on energy: Speeches and writings of E. F. Schumacher. London: Cape. (Original work published 1982)

Schumacher, E. F. (1973). Small is beautiful: Economics as if people mattered. New York: Harper \& Row.

Schumacher, E. F. (1974). The age of plenty: A Christian view. Edinburgh, Scotland: St. Andrew's.

Schumacher, E. F. (1977). A guide for the perplexed. New York: Harper \& Row.

Schumacher, E. F. (1979). Good work. New York: Harper \& Row.

Tanzer, M. (1974). The energy crisis. New York: Monthly Review Press.

Titmuss, R. M. (1959). Essays on the welfare state. New Haven, CT: Yale University Press.

United Nation Conference on Trade and Development. (1975). An international code of conduct on the transfer of technology. New York: United Nations.

Wade, N. (1975). E. F. Schumacher: Cutting technology down to size. Science, 189, 199-201.

Wood, B. (1984). Alias papa: A life of Fritz Schumacher. New York: Harper \& Row.

Roli Varma is an associate professor in the School of Public Administration at the University of New Mexico. She has published on restructuring of corporate $R \& D$ laboratories, women and minorities in information technology, Asian Americans in science and engineering, and ethical issues in science. She can be reached at varma@mgt.unm.edu. 